\title{
Medical lourimal
}

\section{Efficacy of a triple therapy for H elicobacter pylori eradication in a well-developed urban area in Brazil}

\author{
D epartment of Clinical Gastroenterology, Faculdade de M edicina da \\ Fundação ABC, Santo André, São Paulo, Brazil
}

\section{Patrick Bellelis \\ - Eliana Sueco Tibana Samano \\ - Ricardo C ruz $\mathrm{N}$ unes \\ - Lia de Melo Ribeiro \\ - Ethel Zimberg C hehter \\ - W ilson Roberto Catapani}

\section{INTRODUCTION}

Since the first evidence emerged in 1983, further evidence has accumulated that H elicobacter pylori ( $\mathrm{H}$. pylori) plays a major pathogenetic role in peptic ulcer disease. ${ }^{1} \mathrm{~A}$ meta-analysis ${ }^{2}$ study has shown that $H$. pylori eradication reduces peptic ulcer recurrence. Thus, $H$. pylori eradication has become the treatment of choice for curing peptic ulcer disease and preventing ulcer complications. ${ }^{1}$

$H$. pylori eradication is indicated for all patients with peptic ulcer, especially in cases of duodenal ulcers that are not induced by aspirin or nonsteroidal anti-inflammatory drugs (N SAID s), including those with complications. It is al so indicated in cases with lowgrade gastric mucosa-associated lymphoid tissue lymphoma or atrophic gastritis, and following gastric cancer resection. ${ }^{1}$

0 ne-week regimens consisting of omeprazole $20 \mathrm{mg}$ b.i.d., amoxicillin 1,000 mg b.i.d. and clarithromycin 500 mg b.i.d. have been widely used in $H$. pylori eradication. H owever, studies with these drugs performed in some countries, including the United States and France, have had success rates ranging from $66 \%$ to $86 \%$ and from $56 \%$ to $84 \%$, respectively. ${ }^{3}$

It is known that $H$. pylori develops resistance to two groups of drugs: nitroimidazoles (tinidazoleand metronidazole) and macrolides (clarithromycin and azithromycine). The primary resistance of $\mathrm{H}$. pylori strains to macrolides appears to be approximately $10 \%$, but this may cause a significant decrease in the eradication rate. ${ }^{3}$

Clarithromycin seems to be an important component in eradication therapies because of the good results obtained when used on its own and in association. In Brazil, primary re sistance to clarithromycin is still low, less than $5 \%,{ }^{3}$ while in other countries it might be less than $10 \%{ }^{3}$

The aim of this study was therefore to retrospectively determine the $\mathrm{H}$. pylori eradication rate with triple therapy using lansoprazole, amoxicillin and clarithromycin (LAC) for seven days, in patients with peptic ulcer disease from a well-developed urban Brazilian region (the $A B C$ area of the São Paulo metropolitan region). The question was what kind of therapeutic pattern this region would have: whether it would be similar to well-developed countries or not.

\section{METHODS}

This was a retrospective, open-label study carried out at the School of M edicine of the Fundação ABC. It included 130 patients with peptic ulcer disease (upper endoscopy) who had been tested positive for $H$. pylori infection (urease test, histology or breath test), without previous treatment. Patients were treated with lansoprazole $30 \mathrm{mg}$, amoxicillin $1,000 \mathrm{mg}$ and clarithromycin $500 \mathrm{mg}$ b.i.d. for seven days. Eradication was verified after 90 days by means of the urease test, breath test or upper endoscopy.

\section{Statistical analysis}

The statistical analysis was performed using the N CSS-2000 software (Utah, U nited States) for descriptive analysis of frequencies. For correlations between discrete variables we

\section{ABST RACT}

CONTEXT: Helicobacter pylori eradication has become the standard treatment for peptic ulcer disease. Triple therapy with omeprazole plus two antibiotics has been used. Due to the lack of ideal treatment and the high rates of primary resistance to nitroimidazoles, the use of clarithromycin has been adopted.

OBJ ECTIVE: To determine the Helicobacter pylori eradication rates using lansoprazole, amoxicillin and clarithromycin for seven days, in patients with peptic ulcer dise seven days, in patients with peptic ulcer disease in a well
developed urban area in Brazil.

METHODS: This was a retrospective, open-label study carried out at the School of M edicine of the Fundação ABC. It included 130 patients with peptic ulcer disease (upper endoscopy) who had been tested positive for Helicobacter pylori infection (urease test, histology or breath test), without previous treatment. Patients were treated with lansoprazole $30 \mathrm{mg}$, a moxicillin $1,000 \mathrm{mg}$ and clarithromycin $500 \mathrm{mg}$ b.i.d., for seven days. Eradication was verified after 90 days.

RESULTS: Follow-up data were available for 94 patients. Their mean age was 52.23 years; patients. Their mean age was 52.23 years; $37.69 \%$ smokers, $20.77 \%$ using nonsteroidal $37.69 \%$ smokers, $20.77 \%$ using nonsteroidal
anti-inflammatory drugs and $8.46 \%$ alcoholics. Upper endoscopy revealed that $78.46 \%$ had duodenal ulcers and $21.53 \%$ had gastric ulcers (a 4:1 DU:GU ratio). The eradication rates were $85.11 \%$ per protocol and $61.54 \%$ by intention to treat; $97 \%$ had no adverse effects.

CONCLUSION: Triple therapy using lansoprazole, amoxicillin and clarithromycin is well tolerated with high eradication rates and forms a good alternative for developing countries.

KEY WORDS: Helicobacter pylori. Antibiotics. Therapy. Duodenal ulcer. 
used the chi-squared test and Fisher's exact test. Weal so utilized variance analysis between the eradicated, non-eradicated and dropout groups. $p<0.05$ was considered significant throughout the study.

RESULLTS

Follow-up data were available for 94 patients. Sixty-seven were female (51.54\%) and the mean age was 52.23 years. Tobacco and N SAID s users made up a small number in the group, as did alcoholic patients. The majority were born in Brazil's southeastern re gion $(62.31 \%)$ and came from the $A B C$ re gion $(82.32 \%$ ) (Table 1$)$.

\begin{tabular}{lcc}
\hline \multicolumn{3}{|c|}{$\begin{array}{c}\text { Table 1. Baseline data in peptic } \\
\text { ulcer disease population }\end{array}$} \\
\hline \multicolumn{3}{|c}{ n } \\
\hline W omen & 67 & 51.54 \\
\hline M en & 63 & 48.46 \\
\hline W hite & 107 & 82.31 \\
\hline Southeastern region & 81 & 62.31 \\
\hline ABC region & 107 & 82.32 \\
\hline Tobacco users & 49 & 37.69 \\
\hline Alcohol users & 11 & 8.46 \\
\hline N SA IDs users & 27 & 20.77 \\
\hline$n=$ number; N SA IDs: nonsteroidal anti-inflammatory drugs.
\end{tabular}

\section{Table 1. 2. Main results in peptic ulcer} eradication in the $A B C$ region

\begin{tabular}{lcc} 
& $\mathbf{n}$ & $\%$ \\
\hline Gastric ulcers & 28 & 21.53 \\
\hline Duodenal ulcers & 102 & 78.46 \\
\hline DU:GU & $102: 28$ & $3.64: 1$ \\
\hline Control after treatment & 94 & 72.31 \\
\hline Adverse events & 3 & 2.31 \\
\hline Eradication per protocol & 80 & 85.11 \\
Eradication by & 80 & 61.54 \\
intention to treat & & \\
\hline n = number; DU: duodenal ulcer; GU: gastric ulcer. &
\end{tabular}

There were nearly four times more duodenal ulcers than gastric ulcers. The $\mathrm{H}$. pylori eradication rates were $85.11 \%$ by per protocol analysis and $61.54 \%$ by intention to treat analysis. The primary endoscopy found 117 scarred ulcers and 13 active ulcers, all of which were positive for $\mathrm{H}$. pylori infection. Upper endoscopy revealed that $78.46 \%$ of the patients had duodenal ulcers and $21.53 \%$ had gastric ulcers (a 4:1 DU:GU ratio). The active ulcers were duodenal, and therefore upper endoscopy after treatment was not available: only the breath test was (Table 2).

The treatment compliance was $72.31 \%$, with low rates $(3 \%)$ of adverse effects.

\section{Statistical analysis}

No statistically significant correlations could be found between eradication and the use of tobacco, alcohol or N SAID s, or between eradication and demographic data such as age, gender and race. Variance analysis did not find a significant statistical correlation between the eradicated, non-eradicated and dropout groups, for age.

\section{$\ldots \ldots$ DISCUSSION}

The $A B C$ region consists of seven cities (D iadema, M auá, Ribeirão Pires, Rio G rande da Serra, Santo André, São Bernardo do Campo and São Caetano do Sul) in the São Paulo M etropolitan Region, with 2.5 million inhabitants. This is one of the most industrialized areas of Brazil and it has a per capita income of $U \$ 3,250.00$, thereby making this the third biggest market in Brazil, after São Paulo and Rio de Janeiro. ${ }^{4}$

Santo Andréand São Bernardo do Campo have the best $\mathrm{H}$ uman $\mathrm{D}$ evelopment Index (H DI) ( 0.813 and 0.808 respectively) in this region. ${ }^{4}$ About $83 \%$ of the patients studied werefrom these cities, and this population was thus characterized as having a higher socioeconomic level than the Brazilian population as a whole. The majority of the population studied consisted of white people and were not tobacco, alcohol or N SAID s users.

$T$ he male female ratio in the $A B C$ region is approximately 1:1 (51\% women), which is similar to what was found in our study. This result differs from what wasfound in aFrench population, where there was male predominance $(2: 1) .{ }^{3} \mathrm{H}$ owever, this difference did not significantly affect the eradication rates, nor did the age and tobacco use. ${ }^{1}$

The mean age of our patients was 52.2, which is a little older than what was found in other studies (44 to 50 years). ${ }^{3}$ T heoretically, this could represent late infection, due to the better living conditions of our population.

The eradication rates from triple therapy have been found to vary from center to center around the world. ${ }^{5}$ The reason for such differences is not clear, but many factors seem to be involved. 0 ur study found eradication rates that were similar to the rates in another center, which ranged from $78 \%$ up to $90 \%$ per protocol, using 10-day schedules. ${ }^{5} \mathrm{O}$ ur intention-to-treat group had a lower eradication rate $(61.54 \%)$ than for studies using 10 days of treatment (69\% to $83 \%))^{5}$ This low eradication rate in the intention-to-treat group could be explained by our high dropout rate $(27.7 \%)$. We believe that this high dropout was due to the improvement of patients' clinical symptoms.

H owever, because of the high nitroimidazole resistance rate in Brazil, a search for new therapeutic schedules is necessary.

Although triple therapy based on lansoprazole, amoxicillin and clarithromycin is more expensive than bismuth, metronidazole and tetracycline, its use is justified by the high nitroimidazole resistance rate among our population. It is also convenient to use, since it is sold in blister packs.

CONCLUSION

Triple therapy using lansoprazole, amoxicillin and clarithromycin is well tolerated, shows high eradication rates and is a good alternative for developing countries. 
1. G eorgopoulos SD, Ladas SD, Karatapanis S, M entisA, Spiliadi C, ArtikisV, et al. Factors that may affect treatment outcome of tripleH elicobacter pylori eradication therapy with omeprazole, amoxicillin, and clarithromycin. Dig D is Sci. 2000; 45(1):637.

2. Silva FM, Zaterka S, Eisig JN, Chehter EZ, Chinzon D, Laudanna AA. Factors affecting $\mathrm{H}$ elicobacter pylori eradication using a seven-day triple therapy with a proton pump inhibitor, tinidazole and clarithromycin, in brazilian patients with peptic ulcer. Rev H osp Clin Fac M ed Sao Paulo. 2001;56(1):11-6.

3. M isiewicz $\mathrm{G}, \mathrm{H}$ arris $\mathrm{A}$. Clinician's $\mathrm{M}$ anual on $\mathrm{H}$ elicobacter pyIori. $2^{\text {nd }}$ ed. London: Life Science Communications; 1997.

4. Consórcio Intermunicipal do Grande ABC - D ados Regionais. Available from URL: http://www.consorcioabc.org.br/ dados regionaishtm. Accessed in 2004 (Jan 13).

5. Laine L, Suchower L, Frantz J, Connors A, N eil G. Twicedaily, 10-day triple therapy with omeprazole, amoxicillin and clarithromycin for $\mathrm{H}$ elicobacter pylori eradication in duodenal ulcer disease: results of three multicenter, double-blind, U nited States trials. Am J Gastroenterol. 1998; 93(11):2106-12.
Publ ish ing in formation Patrick Bellelis. Sixth-year student, Faculdåde de M édicinà da Fundação ABC, Santo André, São Paulo, Brazil.

Eliana Sueco Tibana Samano. Sixth-year student, Faculdade de Medicina da Fundação ABC, Santo André, São Paulo, Brazil.

Ricardo Cruz Nunes. Sixth-year student, Faculdade de Medicina da Fundação ABC, Santo André, São Paulo, Brazil.

Lia de Melo Ribeiro. Sixth-year student, Faculdade de Medicina da Fundação ABC, Santo André, São Paulo, Brazil.

Ethel Zimberg Chehter, MD, PhD. Adjunct professor, Discipline of Clinical G astroenterology, Faculdade de Medicina da Fundação ABC, Santo André, São Paulo, Brazil.

Wilson Roberto Catapani. Chairman of Discipline of Clinical Gastroenterology, Faculdade de Medicina da Fundação ABC, Santo André, São Paulo, Brazil.

Sources of funding: $\mathrm{N}$ ot declared

Conflict of interest: $\mathrm{N}$ ot declared

Date of first submission: February 27, 2003

Last received: July 16, 2003

Accepted: 0 ctober 6,2003

Address for correspondence: Ethel Zimberg Chehter

Alameda Itu, 820/41 - Cerqueira Césa

São Paulo/ SP - Brasil - CEP 01421-000

Tel./ Fax (+55 11) 3257-2057

E-mail: chehter.ops@zaz.com.br

RESUMO

Eficácia do esquema tríplice na erradicação da $\mathrm{H}$ elicobacter pylori em região urbana desenvolvida de São Paulo

CONTEXTO: A erradicação do Helicobacter pylori tem sido o principal tratamento para a doença ulcerosa péptica. Consiste em uma terapia tripla com omeprazol juntamentecom dois antibióticos. D evido à inexistência de uma medicação ideal, assim como a um alto índice de resistência primária aos nitroimidazólicos em nosso meio, tem-seadotado o uso da claritromicina.

O BJET IVO S: D eterminar o índice deerradicação do Helicobacter pylori em pacientes com doença ulcerosa péptica mediante a terapia com Ianzoprazol, amoxicilina eclaritromicina, por sete dias.

MÉTO D OS: Num estudo retrospectivo, aberto e realizado na Faculdade de M edicina do $A B C$, foram incluídos 130 pacientes portadores de doença ulcerosa péptica (endoscopia digestivaalta) e com infecção por H licobacter pylori diagnosticada pelos testes da urease, respiratório e histológico; todos sem trata- mento prévio. Os pacientes foram tratados com lanzoprazol (30 mg), amoxicilina (1.000 $\mathrm{mg}$ ) e claritromicina $(500 \mathrm{mg}$ ) duas vezes ao dia por sete dias. 0 s índices de erradicação foram avaliadosnoventa dias apóso tratamento.

RESU LTAD 0 S: 94 pacientes completaram o estudo, sendo a média de idade 52,23 anos, $51,54 \%$ mulheres, $84,31 \%$ brancos, $37,69 \%$ tabagistas, 20,77\% usuários de antiinflamatóriosnão-hormonaise $8,46 \%$ de etilistas. A endoscopia digestiva alta revelou: $78,46 \%$ de úlcera duodenal (UD) e 21,53\% de úlcera gástrica (UG) (4UD:1UG). 0 índice de erradicação por protocolo foi de $85,11 \%$ e por intenção de tratamento foi de $97 \%$. Foram observados poucos efeitos colaterais.

CONCLUSÃO: A terapia tríplice com lanzoprazol, amoxicilina e claritromicina mostrou-se bem tolerável, com altos índices de erradicação, sendo uma boa alternativa para países em desenvolvimento.

PALAVRAS-CHAVE: Tratamento. Ú Icera péptica. Helicobacter pylori. Antibióticos. Úlcera gástrica. Úlcera duodenal. 